\title{
DIREITOS HUMANOS ONTEM E HOJE: CARACTERÍSTICAS E REMINISCÊNCIAS DA TRADIÇÃO CLÁSSICA NA DOGMÁTICA MODERNA
}

\section{HUMAN RIGHTS YESTERDAY AND TODAY: CHARACTERISTICS AND REMINISCENCES OF THE CLASSICAL TRADITION IN MODERN DOGMATICS}

\author{
Daniel Nunes Pêcego ${ }^{1}$ \\ Guilherme Cundari de Oliveira Amâncio ${ }^{2}$
}

\section{RESUMO}

A Declaração dos Direitos do Homem e do Cidadão de 1789 e a Declaração Universal dos Direitos Humanos de 1948 representam dois dos mais importantes documentos sobre direitos humanos da história e, no entanto, encarnam espíritos diferentes: a primeira, nascida em seio liberal e individualista, e a segunda, fruto do ânimo de reconciliação após graves crises internacionais. No presente artigo, procurou-se estudar o quanto há de resgate da tradição filosófica clássica no documento mais recente, e o que isso representa na análise da dogmática jurídica moderna. Em conclusão, encontrou-se que de fato a Declaração Universal reconcilia as visões de direito com aquelas trazidas pelos jurisconsultos romanos, e que esta visão, no que toca os direitos humanos, está intimamente ligada às de lei natural e justo/direito natural.

Palavras-chave: Direitos Humanos. Lei natural. Declaração Universal dos Direitos Humanos.

\begin{abstract}
The Declaration of the Rights of the Man and of the Citizen of 1789 and the Universal Declaration of Human Rights of 1948 represent two of the most important human rights documents in history, and yet they embody different spirits: the first, born liberal and individualistic, and the second, as the fruit of the reconciliation animus after serious international crises. In the present research, we tried to study how much of the classic philosophical tradition is rescued in the most recent document, and what this represents in the analysis of modern legal dogmatics. In conclusion, it was found that in fact the Universal Declaration reconciles the visions of law with those brought by the Roman jurisconsults, and that this vision, as far as human rights are concerned, is closely linked to those of natural law and natural right.
\end{abstract}

\footnotetext{
${ }^{1}$ Doutor, Mestre e Bacharel em Direito pela Universidade do Estado do Rio de Janeiro (UERJ). Especialista (PósGraduação Lato Sensu) em Filosofia Medieval pela Faculdade de São Bento do Rio de Janeiro. Professor da Faculdade de Direito da UERJ e do Programa de Pós-Graduação em Direito da UERJ. Unversidade do Estado do Rio de Janeiro - UERJ - Brasil. ORCID: https://orcid.org/0000-0002-1231-1637 Lattes: http://lattes.cnpq.br/4286897515253047 E-mail: dpecego@gmail.com

${ }^{2}$ Graduando em Direito pela UERJ. Foi bolsista de Iniciação à Docência do CETREINA-UERJ (2017-2018). É pesquisador do Laboratório Interdisciplinar de História do Direito (LIHD-UERJ) e membro do Núcleo de Estudos e Pesquisas em Direito Internacional (NEPEDI-UERJ). Editor-chefe da Revista Contexto Jurídico e Editor de Texto da Revista da Faculdade de Direito da UERJ - Brasil. Lattes: http://lattes.cnpq.br/2937760520604797 Email: guicundari@gmail.com.
} 
Keywords: Human Rights. Natural law. Universal Declaration of Human Rights.

"Cum inter nos cognationem quandam natura constituit" $^{3}$

(Digesto, 1.1.3)

\section{INTRODUÇÃO}

Os direitos humanos são tema de profundo interesse jurídico, em particular na esfera do Direito Internacional, principalmente a partir das graves violações ao senso de humanidade percebidas após as duas Grandes Guerras. Em consonância com o espírito reunificador e diplomático surgido na Europa neste período, a ONU publica sua Declaração Universal dos Direitos Humanos, que contém trinta artigos que declaram um conjunto de direitos e deveres fundamentais igualmente a todos os homens a fim de salvaguardar sua dignidade. Os termos e conceitos protegidos em suas linhas divergem sensivelmente do espírito sentido na declaração predecessora, da Revolução Francesa, e em boa medida coadunam-se com uma antiga tradição clássica de se enxergar o direito.

Buscou-se neste artigo, enquanto objetivo geral, investigar as influências desta tradição clássica na visão atual dos direitos humanos. Em específico, estudaram-se as características fundamentais que assumem estes direitos humanos em comparação com a noção moderna de direito subjetivo, à luz da Jusfilosofia aristotélico-tomista e de uma antropologia filosófica clássica. Frente ao problema encontrado pela mudança de paradigma na atual Declaração de 1948, levantaram-se as hipóteses de se a tradição clássica de fato se adequa à noção contemporânea de direitos humanos conforme está no documento referido, e se as noções de coisa justa e justo natural são necessárias à correta compreensão dos direitos humanos.

No fito de encontrar as respostas a tais hipóteses, partiu-se de um marco teórico calcado nos pensamentos de Aristóteles, Tomás de Aquino, Francisco de Vitória e na tradição dos jurisconsultos do Corpus Iuris Civilis, em especial Ulpiano e Gaio, de modo a confrontar as noções contemporâneas e clássicas com base neste lastro literário e também com os documentos normativos do século XVIII e o de 1948.

\footnotetext{
3 “A natureza constituiu entre todos nós certo parentesco".
} 
Desta maneira, foi necessário começar com um excurso acerca da natureza metafísica do homem, posto que é este, em função de sua humanidade, o titular dos direitos que serão analisados. Em seguida, partiu-se para a investigação da visão do direito na tradição clássica e na via modernorum iniciada por Guilherme de Ockham, procurando estabelecer uma relação entre direito e justiça. Por fim, abordaram-se os direitos humanos à luz desta relação, delineando suas principais características enquanto um justo natural.

\section{EXCURSO: O HOMEM ENQUANTO ANIMAL SOCIAL E RACIONAL}

Diógenes Laércio ([1925], p. 43; tradução nossa), famoso biógrafo grego, escreveu que "Platão definiu o homem como um animal, bípede e sem penas, e foi aplaudido. Diógenes [de Sínope] arranjou uma galinha depenada e a trouxe com as palavras 'eis aqui o homem de Platão'. Em consequência disso, ‘... e que tem unhas largas' foi adicionado à definição’. À parte o cinismo de Diógenes e do aspecto pitoresco da definição platônica, reside uma discussão que envolve tanto a Lógica quanto a Metafísica: o método das definições.

Dentre os diversos métodos desenvolvidos no decurso da Filosofia, um dos mais famosos - e utilizados - é a definição genus-differentia, um método lógico-intensivo ${ }^{4}$ proposto por Aristóteles. Para o Estagirita, todos os existentes são divididos em dez categorias ${ }^{5}$ e classificados em uma ou outra pela essência (to ti ên einai, literalmente "o que era para ser", traduzido pelos romanos como essentia). Além de situar os existentes em alguma categoria, a essência também os situa em gêneros mais restritos, de modo a ser a característica diferenciadora das substâncias. Assim, a definição deve reproduzir a essência que há nas coisas: “definição é a descrição que exprime uma essência”. (ARISTÓTELES, [2010], 102a3) O método de fazê-lo reside em indagar duas questões sobre o ente: (1) a que grupo ele imediatamente pertence?; e (2) o que é aquilo que o diferencie dos demais integrantes do grupo em que está inserido?

A resposta à primeira pergunta chama-se gênero (genus); a da segunda, diferença (differentia). Na definição de Platão, segundo Diógenes Laércio, o gênero é bípede, sendo este

\footnotetext{
${ }^{4}$ Intensão é a característica da definição que especifica o objeto através de suas características necessárias e suficientes. A extensão, ao contrário, procura definir os objetos através da enumeração daqueles de mesmo tipo.

${ }^{5}$ Categoria, na Lógica aristotélica, é o tipo de gênero que abarca todos os existentes. Diversos agrupamentos de entes podem ser gêneros ou espécies a depender do referencial analítico; as categorias, no entanto, são o nível mais abrangente possível de gênero. Aristóteles elencou dez em seu livro "Categorias" (1b25-2a5), que compõe o Órganon ([2010]): substância, quantidade, qualidade, relação, lugar, tempo, posição, estado ou condição, ação e paixão.
} 
o grupo de animais em que esta espécie está inserida. No entanto, o que o diferencia dos demais integrantes desse gênero, que também são bípedes? Platão selecionou a diferença "sem penas". O fato de Diógenes de Sínope apresentar uma galinha implume contradisse a precisão da definição, sendo, pois, necessário acrescentar-se uma segunda diferença: de unhas largas. Ainda que este não seja um caso de refutação adequada (argumenta-se, por exemplo, que as penas são acidentes da substância, e não sua essência, e que portanto uma galinha depenada ainda seria uma galinha, uma vez que "o que era para ser" é possuir penas), o relato traduz com precisão o debate das definições mediante o método aristotélico ao longo do tempo.

O que seria homem, afinal? Na definição mais corrente, que segue o modelo proposto, é animal [genus] racional [differentia], e continuará desta maneira até que, hipoteticamente, o homem encontrasse alguma outra forma de vida animal inteligente e racional. Nesse momento, outra diferença seria procurada para distinguir tais dois tipos de animais racionais.

No entanto, e é necessário frisar, o avanço das definições por este método, se corretamente empregado, nunca provocará paradoxos, a exemplo de "o homem é um animal irracional" ser substituído por "o homem é um animal racional”. Se a definição é o reflexo da essência, e a essência é a característica metafísica específica (ou seja, relativa às espécies, e não ao gênero ${ }^{6}$ ), então a essência nunca irá conter um par de opostos em si mesma, dado o princípio da não-contradição, fundamental à compreensão da lógica aristotélica. É natural e compreensível a passagem de "bípede implume" a "animal racional", mas não o seria, por exemplo, a "bípede plumado" ou "quadrúpede implume". Assim, não obstante a falibilidade que o homem tem ao realizar suas descobertas, fundamentalmente o conhecimento não é, e não poderia ser, cíclico ou dialético - seu avanço se dá por complementações, adições e refinamentos, e não anulações, antíteses e rupturas.

Ora, não é despropositado o estudo das definições e nem seus critérios metodológicos. Com a "expressão da essência" do homem em mãos, ilumina-se melhor a compreensão de suas necessidades e potências em sociedade; em outros termos, compreende-se mais eficazmente quais deveriam ser seus direitos e deveres uns em relação aos outros, já que não é arrazoado exigir um dever ou proteger um direito estranho à própria natureza do ser que lhe é titular.

Nesta linha, seguimos o entendimento clássico, já mencionado acima, de que a definição do homem é "animal racional". Embora assumamos como bastantes estes dois adjetivos para

\footnotetext{
6 “A espécie está mais próxima da substância primária, enquanto o gênero está dela mais distante” (Idem, [2010], 2b9).
} 
uma definição, por natural que não são bastantes para descrever o todo do homem: as definições e os seres definidos não são intercambiáveis.

Assim, o homem assume inúmeros outros predicados além de "racional"; diga-se ainda que assume até mesmo essencialmente outros predicados além de "racional", embora seja apenas este que configure sua differentia.

O motivo disso pode ser lido também na obra do Estagirita: em seu De Anima, investiga os diversos tipos de almas ${ }^{7}$ e conclui possuir o homem aquela chamada de racional. Diferentemente da alma vegetativa, voltada à reprodução e crescimento, e da alma sensitiva, voltada à mobilidade e sensações, a alma racional tende ao pensamento e à reflexão. Por esta doutrina (De Anima, Livros II e III), a alma racional contém as almas vegetativa e sensitiva desta forma, também é parte do homem crescer, reproduzir, mover-se e sentir; porém, acrescenta a elas uma nova potência e telos: o raciocínio. É neste sentido que se afirma ser essencial ao homem sentir e crescer, mas ser diferenciador do mesmo o uso da razão. A natureza humana apenas realiza-se completamente, portanto, no exercício do pensamento: "todos os homens, por natureza, tendem ao saber" (ARISTÓTELES, [2002], 980a).

A fixação da racionalidade enquanto natureza humana é o marco inicial da Ética e da Política aristotélicas. A doutrina da liberdade de volição enquanto fundamento da responsabilidade moral ou jurídica é corolário da natureza racional do homem: é ela, e não outra coisa, que confere ao ser humano a possibilidade de escolha, enquanto que os demais animais estariam irremediavelmente presos aos instintos e à sua natureza sensitiva.

Se é a differentia da racionalidade que confere ao homem a responsabilidade por seus atos, é também o próprio fundamento de validade para o caráter coercitivo dos vínculos jurídicos e da proteção legal que deles resultam. Portanto, não apenas a Ética, mas também a Política e o Direito são exclusividades do ser humano: “As criaturas irracionais não têm direitos (...), porque não podem sofrer injustiças; logo, não têm direito” (VITÓRIA, [1998], p. 82); “nec enim potest animal iniuria fecisse, quod sensu caret" 8 (Digesto, 9.1.1.3).

Cumpre ressaltar, por fim, outro elemento de suma importância no homem: sua sociabilidade. A também clássica definição de zoon politikón integra, na tradição aristotélica, a

\footnotetext{
${ }^{7}$ Naturalmente, atente-se ao fato de que "alma", aqui, possui sentido muito diverso do comum ou religioso. Na doutrina de Aristóteles, alma (no original, psyche) é o elemento formal (assemelhado ao sentido de "forma" eidos de Platão) e essencial do corpo. Em seus próprios termos, a alma é a "enteléquia primeira de um corpo natural organizado" (ARISTÓTELES, [2011], 214b5), compreendendo-se enteléquia como a tensão de atualização completa das potências de um ente, de sua realização (enteléquia, etimologicamente, traduzir-se-ia para "conter internamente a finalidade").

8 "Um animal não pode agir com culpa pois carece de razão".
} 
natureza humana de forma inalienável. Ao afastar-se da vida em sociedade, ou mesmo ao alienar-se completamente das consequências desta vida (do exercício da política ou cidadania), o homem estará sub-realizando a própria natureza, e, portanto, incorrendo em um ato de imoralidade e injustiça:

É evidente, pois, que a cidade faz parte das coisas e da natureza, que o homem é naturalmente um animal político, destinado a viver em sociedade, e que aquele que, por instinto, e não porque qualquer circunstância o inibe, deixa de fazer parte de uma cidade, é um ser vil ou superior ao homem. Tal indivíduo merece, como disse Homero, a censura cruel de ser um sem família, sem leis, sem lar. Porque ele é ávido de combates, e, como as aves de rapina, incapaz de se submeter a qualquer obediência. (...) O homem só, entre todos os animais, tem o dom da palavra; (...) a palavra tem por fim compreender o que é útil ou prejudicial, e, em consequência, o que é justo ou injusto. O que distingue o homem de um modo específico é que ele sabe discernir o bem do mal, o justo do injusto, e assim todos os sentimentos da mesma ordem cuja comunicação constitui precisamente a família do Estado. (ARISTÓTELES, [2009], 1253a2-20; destaques nossos)

Nota-se, portanto, a imprescindibilidade da vida em comunidade por parte do homem, e que esta vida em comunidade é também ela uma consequência da racionalidade, enquanto elemento distintivo que separa a justiça da injustiça e, através disso, ordena o convívio comum. Por estas razões, convém analisar o homem enquanto animal social e racional, e buscar nesta natureza a raiz de quaisquer titularidades de direito que este venha a assumir - sendo o homem, e apenas o homem, capaz de fazê-lo dentre os animais.

\section{O DIREITO COMO COISA JUSTA}

Ensina Ulpiano que "iuri operam daturum prius nosse oportet unde nomen iuris descendat. Est autem a iustitia appelatum" " 9 (Digesto, 1.1.1pr.). Embora em sua etimologia no português ("direito", ao contrário de "jus", possui outra raiz) haja um distanciamento desse significado, a tradição jurídica romana nunca deixou de associar intimamente o direito à justiça. No entanto, esta posição caiu em descrédito desde o século XIV, época do surgimento do subjetivismo jurídico.

Segundo Michel Villey (1976, p. 174 apud BONALDO, 2009, p. 122), Guilherme de Ockham, em seu Opus nonaginta dierum, propôs sua tese em defesa dos franciscanos contra as pretensões do Papa João XXII. O Pontífice revivia, àquela altura, um antigo problema enfrentado pela Ordem Franciscana, que era conciliar o grande prestígio e bens materiais de

\footnotetext{
9 "Quem for se dedicar ao estudo do direito precisa antes conhecer de onde deriva o nome ius. Provém de iustitia".
} 
que gozavam com a regra, transmitida por São Francisco de Assis, de viver em pobreza e desprendimento das coisas materiais, tal qual Jesus Cristo havia feito. Os franciscanos buscavam isso separando a propriedade, o dominium, do uso dos bens, que haveriam de ser utilizados de modo desinteressado ${ }^{10}$. Esta posição foi seguida pelos papas do século XIII, até que João XXII, jurista de formação e embebido na tradição aristotélica, considerou imprópria a separação entre o uso e o direito, pois "nossos atos não seriam justos se não se fundassem sobre jura" ${ }^{11}$.

A defesa de Ockham, como é óbvio, foi nutrida pelo nominalismo e voluntarismo presentes em sua filosofia. O primeiro foi responsável por dar uma reposta à querela dos universais e trazê-los, das alturas, para dentro da mente humana, enquanto construções da inteligência subjetiva, dificultando assim a compreensão de algum "justo objetivo" universal; o segundo foi a matriz teórica de onde nasce, essencialmente, o subjetivismo jurídico moderno. Para o franciscano inglês, a base da Ética é o primado da vontade sobre a razão, seja esta vontade divina ou humana. Assim, tanto a noção de Deus como a noção de bem estariam fora do escopo da razão, prevalecendo a vontade, o sentimento, o livre-arbítrio ${ }^{12}$.

Fiel aos princípios nominalistas, Ockham inicia a sua investida elaborando definições pessoais e inéditas dos vocábulos jurídicos que protagonizam a contenda: usus facti (uso de fato), usus juris (uso de direito), jus utendi (direito de uso), res usu consumptibles (coisas consumíveis pelo uso), dominium (domínio), proprietas (propriedade) (BONALDO, 2009, p. 123).

Divide, ainda, as fontes do direito em duas: uma divina, advinda de Deus (ius poli, direito do céu), e uma terrena, advinda da sociedade civil em virtude do direito positivo, o ius fori, direito de foro (Ibid., loc. cit.). Em ambos os casos, o homem estaria autorizado, por lei humana ou divina, a fazer uso das coisas terrenas; em outros termos, teria a faculdade de agir. Esta faculdade, por sua vez, é compreendida enquanto um poder individual.

A esta altura já é possível visualizar, logo em Ockham, a definição contemporânea de direito subjetivo: uma facultas agendi, tida na prática enquanto uma potestas, garantida por uma norma agendi, o direito objetivo.

Por este ângulo, perde-se o caráter relacional do direito, a imperatividade da justiça do vínculo, a équa medida da distribuição dos deveres e encargos. "Para a metafísica de Ockham,

\footnotetext{
${ }^{10} \mathrm{Na}$ Bula Ordinem vestrum, Inocêncio IV deixa à disposição da Ordem os bens, mas, ao mesmo tempo, “in jus et proprietatem Beati Petri" [i.e., no direito e propriedade de São Pedro], vinculados oficialmente à Santa Sé. (VILLEY, 1976, p. 152 apud BONALDO, 2009, p. 121)

${ }^{11}$ Note-se, aqui, que o termo ius ainda mantinha seu sentido clássico original.

12 Sobre o voluntarismo em Duns Scotus e Guilherme de Ockham, vide VILLEY, 2009, p. 201-288.
} 
não há relações no mundo, somente indivíduos. A consequência antropológica é a definição de ser humano como indivíduo, isto é, alguém cuja identidade deve ser dada à margem da relação com os demais seres humanos" (BARZOTTO, 2004, p. 154-155). Observa-se aqui o abandono da importância da natureza política ou social do homem para a análise do direito, cujas consequências podem ser observadas, no tocante aos direitos humanos, na Declaração dos Direitos do Homem e do Cidadão.

Concebido no seio de uma revolução liberal no século XVIII, este documento declara em seus artigos uma série de garantias civis e políticas com o fito de proteger o homem do Estado que outrora eclipsava suas potências. Fazendo referência até mesmo ao direito natural (art. $2^{\circ}$ ) enquanto finalidade da associação política, a declaração no entanto carece de remissões à sociedade e à alteridade das relações políticas, impondo não ligações entre os sujeitos de direito, mas limitações entre os mesmos: o direito passa aqui a ser instrumento potencialmente contencioso, uma norma agendi que o cidadão, lesado pelo outro, procura para validar sua potestas sobre algum bem ou obrigação. Ainda que não explicitamente, o direito cede sua capacidade preceptiva de deveres para a sancionatória de delitos: "a liberdade, como direito do homem nas declarações do século XVIII, não se funda nas relações entre o homem e o homem, mas antes na separação do homem a respeito do homem" (BARZOTTO, 2004, p. 156)

Cumpre, a bem de harmonizar o conceito de direito com a antropologia filosófica discutida na seção anterior, buscar na literatura clássica alguma resposta diversa para a questão. Encontramos em Tomás de Aquino o confronto direto com o problema (S. Th., II ${ }^{\mathrm{a} I \mathrm{I}^{\mathrm{ae}}}$, q. 57, a. 1): ultrum jus sit objectum justitiae? ${ }^{13}$

$\mathrm{O}$ artigo inicia-se por elencar uma objeção de Celso ${ }^{14}$, segundo a qual o direito seria uma virtude intelectual (sed est per se virtus intellectualis), e portanto não o objeto da justiça (ergo ius non est objectum iustitiae).

Em seguida, uma objeção de Isidoro de Sevilha, que elenca a lei como uma espécie de direito. Ora, a lei é objeto da prudência (lex autem non est obiectum iustitiae, sed magis prudentiae), logo o direito não é objeto da justiça.

Por fim, outra objeção de Isidoro de Sevilha, agora citando Agostinho, segundo a qual a justiça é o amor que apenas serve a Deus (iustitia est amor Deo tantum serviens). Assim, como o direito tem a ver com homens, e não com Deus, não poderia ser objeto da justiça.

\footnotetext{
13 “Jus é ou não objeto da virtude de justiça?"

${ }^{14}$ Encontramo-la em Digesto, 1.1.1pr., "ut eleganter Celsus definit, ius est ars boni et aequi”, o direito é a arte do bom e do justo, como geralmente se traduz.
} 
Em contrário - e a conclusão do artigo acompanhará tal posição - Aquino indica outra posição de Isidoro - compilador eclético que fora - segundo a qual

quod Isidorus dicit in eodem quod jus dictum est quia est justum. Sed justum est objectum justitiae: dicit enim Philosophus in V Eth. quod omnes talem habitum volunt dicere justitiam a quo operativi justorum sunt. Ergo jus est objectum justitiae $^{15}$.

Respondendo a estas teses, o Doutor Angélico começa por enunciar a alteridade enquanto própria da justiça (respondeo dicendum quod iustitiae proprium est inter alias virtutes ut ordinet hominem in his quae sunt ad alterum), pelo fato de relações de justiça implicarem em uma certa igualdade (importat enim aequalitatem quandam) e igualdade forçosamente ser uma relação com o outro. Desta forma, o exercício da virtude da justiça não tem como objeto o próprio agente que a pratica, como ocorre com as demais virtudes, mas sim tem seu objeto em si mesmo determinado, que é o justo (secundum se objectum, quod vocatur iustum). Este justo, conclui por fim, chama-se direito (et hoc quidem est ius).

A conclusão do Aquinate remonta claramente, ainda que não expressamente, à doutrina ética de Aristóteles exposta no Livro V de sua "Ética a Nicômaco". Nela, defende o filósofo que a justiça é a virtude mais perfeita que há devido ao fato de ser praticada em relação ao outro, ao bem de uma comunidade, "não sendo nem a estrela vespertina nem a matutina tão admiráveis" (1129b29) quanto esta virtude: “é a virtude perfeita por ser ela a prática efetiva da virtude perfeita, sendo também sua perfeição explicada pelo fato de seu possuidor poder praticála dirigindo-se aos outros, e não apenas praticá-la isoladamente" (1129b30-33). Mais à frente na mesma obra, encontramos também o fundamento para a associação da justiça com a igualdade: "se, então, o injusto é o não equitativo, o justo é o equitativo" (1131a13).

Em verdade, Aristóteles percorreu a mesma investigação de Tomás de Aquino acerca do significado da palavra "justo" (Dikaion) em sua Ética, e, embora partisse de uma raiz etimológica distinta daquela latina de que partiu o dominicano, o resultado foi o mesmo, comprovando a forte raiz aristotélica do Direito Romano:

$\mathrm{Na}$ antiga mitologia grega, à deusa Diké era especialmente atribuída a incumbência de espalhar uma ordem harmoniosa pelo mundo. E a virtude, cuja função é manter ou promover a ordem, é chamada Dikaiosuni; o homem que tem essa virtude, Dikaios. To Dikaion: bastará uma análise gramatical elementar. A palavra é um neutro substantivado. Não significa ação justa, designada por um

15 "É o que diz Isidoro: diz-se jus porque é justum. Mas o justo é o objeto da justiça: o Filósofo [Aristóteles] diz no livro V de Ética que todos convêm em chamar de justiça a virtude pela qual os homens realizam coisas justas. Portanto, jus é o objeto da justiça". 
verbo constituído a partir da mesma raiz (dikaioprattein). Nem seu sujeito, o dikaion. Mas esse objeto, a coisa justa (VILLEY, 2014, p. 115; destaques no original).

Esta "coisa", por sua vez, não deve ser lida enquanto um bem material, no sentido jurídico moderno, mas sim na concepção romana clássica de res, que se perdeu com o tempo. Dentre as diversas classificações deste conceito, importam para este artigo duas: as res corporales e res incorporales.

As primeiras são todas aquelas coisas que podem ser tocadas, que são dotadas de materialidade. Não cabe confundir aqui, no entanto, o conceito de corpus com o de res: uma res é um corpus juridicamente considerado; é um corpo material sobre o qual repousa uma relação de adequação (aequitas) entre pessoas (ad alterum); é um corpus cum iure suo ${ }^{16}$. Essas res corporales podem abarcar mais de um corpus dotado de autonomia material, como um terreno (fundus) e tudo o que há sobre ele, e ainda assim falaremos de apenas uma res: non est separatum corpus a fundo (Digesto, 19.1.40).

Já as res incorporales, cuja concepção é tributária da filosofia grega trazida por Cícero e Sêneca (NÓBREGA, 1976, p. 28), consistem em coisas abstratas, de existência puramente jurídica, que importam relações de justiça. Compõe este gênero as servitutes (servidões), usufructus (usufrutos), hereditas (herança) e obligatio (obrigação). (BONALDO, 2009, p. 82) Seguindo Gaio (Ibid., p. 85-86), são aquelas quae tangi non possunt, qualia sunt e aquae in jure consistunt ${ }^{17}$, vindo daí a associação que os romanistas costumam fazer entre ius e res incorporales como equivalentes.

Assim sendo, a "coisa justa" a que se referem Aristóteles e os jurisconsultos não é o objeto mediato de uma simples obligatio dandi, mas sim a própria obligatio considerada enquanto uma res incorporale, uma relação abstrata entre sujeitos políticos mediados por uma proporção de igualdade calcada na justiça.

Encerra-se esta exposição enunciando a célebre definição de Ulpiano sobre justiça e direito (Digesto, 1.1.10pr. e 1.1.10.1), cuja escolha de palavras agora, após a compreensão destes significados, fará mais sentido: iustitia est constans et perpetua voluntas ius suum cuique tribuendi $^{18}$, e iuris praecepta sunt haec: honeste vivere, alterum non laedere, suum cuique tribuere. ${ }^{19}$ A justiça refere-se a uma vontade, visto que é uma virtude e a premissa da Ética,

\footnotetext{
16 "Com o seu direito".

17 "Que não podem ser tocadas, que consistem em um direito".

18 "Justiça é a vontade constante e perpétua de dar a cada um o que é devido".

19 "São estes os preceitos do direito: viver honestamente, não lesar o próximo, dar a cada um o que é seu".
} 
como se viu, é o livre-arbítrio, corolário da racionalidade; esta vontade deve ser constante, já que, dependente do livre-arbítrio que é, a realização moral não é uma consequência instintiva da natureza, mas o exercício de um hábito ${ }^{20}$; e consiste em dar a cada um o que é seu, por ser um exercício tanto de alteridade (cada um) como de equidade (o que é seu).

Já o direito, por esta definição, deve basear-se tanto na vida honesta quanto em não lesar o outro, sendo um e outro o exercício da justiça e omissão da injustiça, que são, segundo o Estagirita, a suma virtude e o sumo vício (ARISTÓTELES, [2014], 1130a11).

\section{OS DIREITOS HUMANOS COMO JUSTO NATURAL}

Na doutrina contemporânea do direito subjetivo, o homem possui um direito caso tenha para si a faculdade ou o poder de agir sobre algo, fundamentada em uma norma positiva e garantida pelo Estado. A relação de dependência estabelecida a partir daí entre o direito subjetivo e direito objetivo e Estado resulta em uma maneira peculiar de se compreender a titularidade dos direitos: esta se dá em virtude de uma determinada posição no ordenamento jurídico.

O direito de propriedade é exercido caso o sujeito tenha adquirido de alguma forma legítima a propriedade (doação, compra e venda, herança, usucapião); o pátrio poder é exercido a partir da constituição da condição de genitor; o de herdeiro, a partir da ocorrência da morte; o de eleitor, com a inscrição junto ao órgão competente, etc.

Em todo caso, nota-se a necessidade de um status jurídico positivado por determinado ordenamento nacional. É este ordenamento, e não outra coisa, a fonte remota da titularidade, e as relações de justiça variarão de Estado a Estado conforme estes disciplinem o direito objetivo de um modo ou de outro.

No estudo dos direitos humanos, no entanto, o sistema é diferente. Sua titularidade não se dá por constituição de uma soberania, mas pela qualidade de pessoa humana. Às soberanias cabe apenas declará-los e a ausência desta declaração não implica em revogação ou inexistência dos direitos humanos. (BARZOTTO, 2004, p. 126) Esta visão, calcada na premissa de universalidade dos direitos humanos, apesar de não ser unânime, parece ser a mais aceita em

\footnotetext{
20 “A virtude moral ou ética é produto do hábito (...) as virtudes não são geradas nem em decorrência da natureza nem contra a natureza”, ensina-nos Aristóteles ([2014], 1103a15-25).
} 
escala mundial (Ibid., loc. cit.), como se pode inferir inclusive pelo nome do mais importante documento atual sobre o tema: Declaração Universal dos Direitos Humanos.

Ao estudarmos essa dogmática dos direitos humanos sob a ótica do direito enquanto coisa justa, importa inicialmente atentar para o caráter da alteridade contido neste tipo de relação jurídica.

Nos diversos tipos de justiça definidos por Aristóteles em sua "Ética a Nicômaco", que não cumpre comentar nesta abordagem, observam-se diferentes tipos de relação. $\mathrm{O}$ mais particular pode ser lido na justiça comutativa, baseada em um sinalagma entre duas pessoas em uma determinada relação. Como exemplo mais recorrente cite-se a compra e venda, em que o vendedor se obriga a transferir a propriedade de um bem em troca de uma quantia em dinheiro. Na preservação desse sinalagma, a teoria moderna assenta princípios como o da proibição da onerosidade excessiva (art. 478 do Código Civil) e institutos como o da lesão (art. 157) e o do estado de perigo (art. 156). É, portanto, à manutenção da equidade entre os contratantes, em virtude dos termos particulares escolhidos, que se presta o sinalagma desta justiça, não cabendo em consideração, aqui, a relação para com terceiros. No entanto, o teor da relação de justiça altera-se em outras modalidades, como observado também na teoria da justiça conforme proposta por Tomás de Aquino, outra vez influenciado pelo Estagirita.

Em sua "justiça legal”, semelhante ao conceito de justiça universal do filósofo grego, seu objeto próprio é o bem comum, e não o particular. "Pela justiça legal, estabelece-se aquilo que é devido à comunidade para que esta alcance seu bem.” (BARZOTTO, 2004, p. 158) "Comunidade" não é um ente existente per se; trata-se de um coletivo de sujeitos que a compõe como tal. Assim sendo, por extensão, o bem comum da comunidade é o bem de cada membro que a integra.

Nesta leitura, toda dicotomia entre o bem comum da comunidade e o bem particular das relações comutativas é sempre aparente ou equivocada: não se pode admitir que o bem particular negue o bem comum, já que por definição este último é referente a cada membro da comunidade. Assim sendo, o interesse geral, ou bem comum da sociedade é parte integrante do interesse particular ou bem particular dos sujeitos em suas relações. Gize-se aqui, mais uma vez, a natureza intrinsecamente social do homem, como discutida inicialmente neste artigo.

Assim sendo, a realização do homem depende da comunidade, de modo que o bem-estar desta é, em parte, equivalente ao bem-estar daquele. Não podemos deixar de observar, a esta altura, o conflito que esta noção tem com a Declaração Liberal do século XVIII, preocupada em declarar os direitos humanos não enquanto objetos do bem comum que devem ser 
observados enquanto imprescindíveis para a realização de cada bem particular, mas sim enquanto objetos do bem particular que devem ser protegidos da vida em sociedade. A vida, a saúde, a propriedade e a liberdade assumem, no seio individualista deste diploma, limitações e fronteiras nas relações humanas, bens a serem reservados do contato de terceiros, sob risco de perdê-los.

A Declaração Universal dos Direitos Humanos de 1948 encarna espírito diferente daquela, compatível com o marco teórico investigado neste artigo. Em seu artigo I, enuncia imediatamente a consciência e racionalidade do homem ("são dotados de razão e consciência"), em virtude das quais são "livres e iguais em dignidade e direitos", expondo, portanto, tanto a natureza racional do homem, quanto à consequência política desta: os direitos, e em especial os direitos humanos, advindos da mera condição de pessoa humana. Não bastasse isso, no mesmo artigo, ao lado do direito de liberdade, é declarado o dever de fraternidade nas relações sociais, o que afirma não apenas a alteridade do direito, mas a necessidade da comunidade para a realização do homem.

Este espírito percorre todos os artigos do documento da ONU, em que também pode-se ler, em seu artigo XXIX, que "todo ser humano tem deveres para com a comunidade, na qual o livre e pleno desenvolvimento de sua personalidade é possível" - afirmação inédita se comparada aos documentos do século XVIII - expressamente afirmando ser a comunidade o meio natural de desenvolvimento da personalidade do homem, advindo em função disso seu dever para com ela.

Assim sendo, os titulares destes direitos não são apenas os humanos, mas sim os cohumanos (BARZOTTO, 2004, p. 147), uma vez que o exercício dos direitos humanos enquanto tais apenas faz sentido se forem considerados em função do bem comum em que se inserem e que o co-humano também é interessado em sua própria existência digna.

A universalização em caráter absoluto desses direitos aparece-nos, agora, como uma consequência necessária de assumi-los como decorrentes da pessoa humana e da alteridade relativa a ela, considerando que todos os homens compartilham da mesma essência comum expressa no começo deste artigo: ser um animal social e racional. Privar alguém desses direitos, sob quaisquer pretextos, é mais do que um extremo ato de injustiça: é também uma atitude metafisicamente disparatada. Não assumir os direitos humanos como universais, ou fazê-los depender de sua positivação por parte de Estados, é negar a própria essência dos direitos humanos. 
No entanto, se independem da lei positiva e não são constituídos, mas declarados, qual haveria de ser sua fonte?

"Na tradição tomista, o direito ou o justo é definido como aquilo que é adequado a outrem. Mas algo é adequado a outrem de dois modos: ou por convenção, ou por natureza" (BARZOTTO, 2004, p. 160). Considerando o justo estabelecido por convenção, encontramos o pactuado pela vontade particular - contrato - ou pela vontade coletiva - lei - e que varia conforme as necessidades contextuais de cada comunidade que constitui este justo. Já o direito definido por natureza advém das qualidades, potências e necessidades universais dos seres humanos para sua perfeita realização, isto é, para a possibilidade da dignidade inerente a cada pessoa humana.

Desta maneira, por consequência do direito advindo da natureza temos também uma igualdade advinda da natureza: a mesma enunciada pela Declaração Universal em seu referido artigo I, segundo o qual "todos os seres humanos nascem livres e iguais em dignidade e direito" (destaques nossos). Ora, se a essência não pode divorciar-se de cada substância primária, isto é, se a natureza humana não pode variar de pessoa para pessoa, então todos forçosamente terão as mesmas necessidades de realização humana, e, portanto, os mesmos direitos, assim estabelecidos mediante esta equidade natural e universal.

Assim, por exemplo, pode-se dizer que todo ser humano tem direito à saúde, já que sem este predicado a vida é impossível. Universal e decorrente da natureza que é, diz-se que se trata de lei natural, de um justo estabelecido pela natureza, independente de soberanias políticas.

Este justo natural, no entanto, não implica em especificações de forma. Não é naturalmente necessário que a saúde seja atendida por algum sistema público de saúde, ou por sistema particular, ou por caridade voluntária, ou pela própria diligência individual no cuidado com o próprio corpo. É apenas necessário o predicado imprescindível à vida - a saúde - e nada mais. O direito positivo, e não o natural, estará encarregado de, nas contingências culturais e temporais de cada comunidade, efetivar este mandamento da natureza.

Ainda, é importante ressaltar que este mandamento não pode entrar em contradição com a própria noção de bem comum enquanto constitutivo do bem particular. O referido direito à saúde de um indivíduo não pode suplantar por si só a equidade das demais relações sociais estabelecidas pela justiça. Como explica Luis Fernando Barzotto,

Ao contrário, conceber o direito subjetivo à saúde como justo subjetivo é concebêlo como algo ajustado a um ser social, que deve manter uma relação de igualdade com os demais membros da comunidade e cujo bem está ligado ao bem comum, 
não podendo alcançá-lo se destruir este último. Assim, não se trata de saber se é algo adequado ao indivíduo $\mathrm{X}$ receber 10 milhões porque sua doença exige essa quantia para um tratamento eficaz. A saúde de X é uma qualidade individual sua, a ser determinada por um médico. $\mathrm{O}$ direito à saúde não é uma qualidade individual, mas uma relação de justiça que $\mathrm{X}$ mantém com os outros membros da comunidade. A saúde, considerada em si mesma, é algo naturalmente adequado ao ser humano, uma qualidade necessária à sua autorrealização. Mas na sua manifestação histórica, como um direito, ela deve ser considerada nas suas consequências, isto é, como algo devido no interior de uma comunidade, o que relativiza um bem que em si mesmo, é absoluto. Se a comunidade não possui 10 milhões para fornecer a $X$, sem que seu orçamento entre em colapso (bem comum) e/ou inviabilize o tratamento médico devido a outros membros da comunidade (igualdade), a saúde de $\mathrm{X}$ será afetada, mas não o seu direito à saúde, pois 10 milhões não é algo adequado a ele como membro da comunidade, o que significa dizer que os outros membros da comunidade não lhe devem isso. Pensar que o direito à saúde deve ser determinado do ponto de vista do indivíduo isolado é pensá-lo como uma mônada, é retornar ao modelo liberal de estado de natureza, onde os direitos do indivíduo são determinados à margem da vida social (2004, p. 162 ; destaques no original).

Assim, devido a seu vínculo com as necessidades da natureza humana, os direitos humanos são também vinculados intimamente à lei natural: da maneira que os direitos subjetivos modernos são fundamentados na lei positiva, os direitos humanos são fundamentados na lei natural.

\section{CONCLUSÃO}

O homem, em função de sua natureza racional e social, é capaz de possuir responsabilidade moral e jurídica perante os atos que realiza. Estes atos, por sua vez, devem ser calcados em uma relação de justiça delineada por uma equidade correspondente. Desta forma, as ações humanas são precipuamente voltadas à vida em sociedade e seus direitos e deveres são necessariamente dotados de alteridade, sendo a comunidade - e, portanto, o bem comum elementos essenciais da realização do homem e de seu bem particular. Os direitos humanos, medida de justiça que delineia este tipo de relação com base em um fundamento de lei natural, servem então ao propósito de assegurar o reconhecimento da dignidade inerente a toda pessoa humana, e por isso mesmo independem de positivações e nem podem ser alienados de qualquer pessoa.

Esta visão de direitos humanos, cujos principais temas podem ser lidos na Declaração Universal dos Direitos Humanos, representa um retorno à tradição clássica jusfilosófica, rompida no século XIV com o subjetivismo e voluntarismo jurídicos de Guilherme de Ockham. Assim, restou comprovada a hipótese do real vínculo e adequação entre a filosofia aristotélico- 
tomista-romana e a dogmática moderna calcada na Declaração de 1948, embora esta mesma tradição filosófica seja rejeitada pelo restante da dogmática jurídica, geralmente avessa a conceitos metafísicos e profundamente arraigada a potestas que representa o direito subjetivo moderno.

Apesar disso, concluiu-se também como notória a relação entre direitos humanos e lei natural, de modo que o distanciamento entre ambos os conceitos provoca prejuízos à universalidade destes direitos e, em decorrência disso, à própria definiçãa destes direitos enquanto humanos, e não enquanto advindos de status jurídicos particulares. É, portanto, fundamental a compreensão do justo natural na compreensão das relações de direitos humanos.

\section{REFERÊNCIAS}

AQUINO, Sancti Thomae. Summa Theologiae. Disponível em: <http://www.corpusthomisticum.org>. Acesso em: 11 jul. 2018.

ARISTÓTELES. Metafísica. São Paulo: Loyola, [2002].

Política. 2. ed. São Paulo: Edipro, [2009].

Órganon. 2. ed. São Paulo: Edipro, [2010].

. De Anima. São Paulo: Edipro, [2011].

Ética a Nicômaco. 4. ed. São Paulo: Edipro, [2014].

BARZOTTO, Luis Fernando. Os direitos humanos como direitos subjetivos: da dogmática jurídica à ética. Revista da Procuradoria Geral do Estado do Rio Grande do Sul, v. 28, n. 59, p. 137-175, 2004.

BONALDO, Frederico. Consistência teórica do direito subjetivo de propriedade: uma leitura à luz da história do pensamento jurídico. São Paulo: Juarez de Oliveira, 2009.

DIÓGENES LAÉRCIO, Lives and Opinions of Eminent Philosophers in Ten Books. v. 2. Massachusetts: Harvard University Press, [1925].

IMPERATORIS IVSTINIANI OPERA. Disponível em: <http://www.thelatinlibrary.com/justinian.html>. Acesso em: 11 jul. 2018.

NÓBREGA, Vandick L. da. Compêndio de Direito Romano. 9. ed. v. 2. Rio de Janeiro: Livraria Freitas Bastos, 1976. 
VILLEY, Michel. A formação do pensamento jurídico moderno. 2. ed. São Paulo: Martins Fontes, 2009.

Estudios em torno a la noción de derecho subjetivo. Valparaíso: Ediciones Universitarias de Valparaíso, 1976 apud BONALDO, Frederico. Consistência teórica do direito subjetivo de propriedade: uma leitura à luz da história do pensamento jurídico. São Paulo: Juarez de Oliveira, 2009.

2014.

Questões de Tomás de Aquino sobre Direito e Política. São Paulo: Martins Fontes,

VITÓRIA, Francisco de. Sobre los indios. Madri: Tecnos, [1998].

Trabalho recebido em 05 de junho de 2020

Aceito em 05 de junho de 2020 